with hearing impairments, are presented. Application of forms of collaboration through the network is considered, possibilities of using the method of educational projects as possible directions of socialization are described. The conclusions are made about the expediency of using students learning with SEN online services LearningApps, GeoGebra, implementation of the method of educational projects. A tutorial on mathematics teaching methodology is presented, which should be used in the preparation and advanced training of teachers. Successful implementation of the developed system of tasks, selected tools and forms of work requires the additional development of instructional and methodological materials for the assistant teacher (assistant), that is essential for the successful implementation of the Concept of inclusive education. In the future, it is expedient to expand the study of the possibility of using blended learning for the development of cognitive, creative, communicative, and collaborative skills, which are the basic competences of the 21st century for students with SEN.

Keywords: mathematics teaching methodology, stochastics, probability theory and mathematical statistics, students with special educational needs, inclusive learning, distance learning technologies, LearningApps, GeoGebra.

DOI 10.31392/NPU-nc.series 2.2020.22(29).15

УДК: 62:374:004.231.3

Олександр Миколайович Кривонос ${ }^{1}$ Мирослава Петрівна Кривонос²

Житомирський державний університет імені Івана Франка, м. Житомир, Україна ${ }^{1}$ кандидат педагогічних наук, доцент кафедри прикладної математики та інформатики ORCID ID 0000-0002-4211-6541

krypton@zu.edu.ua

${ }^{2}$ асистент кафедри прикладної математики та інформатики ORCID ID 0000-0001-7563-2692 myroslava_kr@meta.ua

\title{
FRITZING - ПРОГРАМА ДЛЯ СТВОРЕННЯ НАОЧНИХ ЕЛЕКТРОННИХ СХЕМ
}

Анотація. В статті проаналізовано сучасний стан проблеми впровадження STEM-освіти в закладах загальної середньої освіти України, розглянуто перспективи запровадження елементів схемотехніки в межах шкільного курсу інформатики, як одного з елементів STEM-освіти і як одного 3 компонентів фахової підготовки вчителя інформатики. Здійснено аналіз досліджень та публікацій 3 проблеми використання електронних пристроїв в навчальному процесі. Авторами статті обгрунтовано вибір відкритого програмного комплексу Arduino, як допоміжного дидактичного засобу вивчення елементів комп'ютерної схемотехніки. Описані найбільш розповсюджені платформи модельного ряду Arduino та наведено приклади застосування зазначених платформ в реальних проектах. Подано основні технічні характеристики електронних елементів, що входять до складу Arduino Uno. Детально розглянуто мікроконтролер Atmega328P, основний обчислювальний центр платформи, та основні складові зазначеного мікроконтролера. Для обгрунтування запропонованої методики розглянуто та описано програму для створення наочних електронних схем Fritzing. Даний програмний продукт надає можливість візуального представлення проекту у різних видах (макет, схема та друкована плата). Будь-яке з цих представлень може використовуватися в якості основного робочого середовища проекту та може бути вибрано в будь-який час. Зазначений програмний продукт має бібліотеку готових проектів, яка значно полегшує процес навчання. Для більшої наочності описано та проілюстровано усі процеси створення прототипу електронної гри «Hunter» в середовищі Fritzing, а також опис процесу створення самої гри. Програмний продукт Fritzing використовується в процесі фахової підготовки майбутній вчителів інформатики, математики та фізики в Житомирському держаному університеті імені Івана Франка. Авторами окреслено подальші напрями досліджень $з$ даної галузі.

Ключові слова: STEM-освіта, схемотехніка, електронні схеми, Arduino.

Актуальність дослідження. В український системі середньої освіти все більшого обговорення та поширення набуває STEM-освіта, де поєднуються проектний і міждисциплінарній підходи, підгрунтям для яких $є$ інтеграція природничих наук у технології, інженерію та математику.

Освіта в галузі STEM є основою підготовки працівників для сфери високих технологій. Тому багато країн, зокрема Великобританія, Китай, Австралія, Ізраїль, Сінгапур, Корея, США, реалізовують державні програми в галузі STЕМ-освіти [1]. 
Навчання за програмою STEM надзвичайно важливе в перспективі. Згідно 3 даними, що оприлюднено на сайті STEMconnector.org, на 2018 рік прогнозувалась потреба у 8,65 млн. працівників на робочі місця, пов'язані зі STEM. Вже сьогодні виробничий сектор потребує спеціалістів із необхідними навичками, їх кількість становить майже 600000 осіб. Очікується, що протягом наступних 10 років потреба в таких фахівцях збільшиться в 4 рази порівняно 3 іншими професіями.

Te, що відрізняє STEM від традиційної науки і математичної освіти, - це змішане середовище навчання, що показує учням, яким чином науковий метод може бути застосований у повсякденному житті. STEM розвиває в учнів практичне й аналітичне мислення та фокусується на реальних засобах розв'язування проблем. Така освіта повинна починатися ще зі шкільної лави, бажано навіть із молодшого шкільного віку [2].

На жаль більшість учителів через відсутність досвіду та знань не спроможні запровадити в навчальний процес зазначену програму. Для подолання цього протиріччя в США, наприклад, була запроваджена національна програма з підготовки вчителів, які готові працювати в єдиній системі природничих дисциплін і технологій [3].

Сьогодні STEM-освіта, що реалізується в українських школах, представлена у формі факультативів та гуртків. Учні, окрім фізики й математики, вивчають основи робототехніки, програмування, створюючи та програмуючи власних роботів. На заняттях використовують, за наявності, специфічне технологічне лабораторне й навчальне обладнання: 3D-принтери, засоби візуалізації та інше. На державному рівні STEM-освіта реалізована у формі низки олімпіад i конкурсів: Intel Techno Ukraine; Intel Eco Ukraine; Фестиваль науки Sikorsky Challenge, FERREXPO ROBOT FEST.

Для підтримки талановитої молоді в більшості обласних центрів створено STEM-центри своєрідні стартові майданчики, де надається необхідна науково-технічна база для подальшого фахового розвитку та становлення [4].

Одним із напрямків впровадження STEM-освіти є схемотехніка. Це науково-технічний напрям, де охоплюються проблеми проектування та дослідження електронних схем.

Для викладачів, вчителів та інших користувачів основним елементом для дослідження може стати платформа Arduino, що дозволить на практичному досвіді засвоїти основні елементи схемотехніки, обчислювальної техніки та електроніки.

Аналіз актуальних досліджень та публікацій. У працях багатьох науковців і педагогів знаходять своє відображення проблема використання електронних пристроїв під час навчального процесу та розробка й опис нових пристроїв. Питанням розвитку технічного, творчого, а також креативного мислення завдяки конструкторській діяльності займалися науковці: Є. Мілерян, Г. Альтшуллер, І. Ройтман, А. Давиденко, Т. Кудрявцев, В. Моляко, П. Якобсон та інші. Такі вчені, як В.Ю. Биков, П. Атаманчук, М.I. Шут, Н. Сосницька, С.М. Смирнова-Трибульська у своїх роботах приділяли увагу методичним і теоретичним основам використання інформаційних технологій під час підготовки майбутнього вчителя $[5,6]$.

Метою проведення дослідження $\epsilon$ аналіз апаратної складової платформи Arduino, ознайомлення з $\dddot{11}$ функціональними можливостями та технічними характеристиками на прикладі плати Arduino Uno; здійснення огляду програмного пакету Fritzing, визначення перспектив його застосування в освітній діяльності та створення наочної електронної схеми засобами програмного пакету Fritzing на прикладі електронної гри.

Подання основного матеріалу дослідження. Arduino - це платформа, що розроблена для прототипування (тобто розробки) різних пристроїв. Сьогодні Arduino стала однією з найпопулярніших платформ у колі прихильників електроніки. Вона приваблює своєю простотою, сумісністю з більшістю операційних систем і низькою вартістю. Також платформа Arduino досить гнучка та придатна для розв'язування широкого кола задач.

Зараз, крім першої платформи Arduino Extreme, існує велика кількість інших плат, спеціально розроблених для певних завдань. Найпоширеніша на сьогоднішній день - платформа Arduino Uno.

Arduino представляє собою плату з розміщеними на ній компонентами, головним із яких $\epsilon$ мікроконтролер. Arduino Uno побудована на базі мікроконтролера ATmega328 з тактовою частотою 16 мГц, виходи якого зручно розведені на краях плати та підписані. У цієї платформи таких виходів 20, 6 із яких аналогові, а решта 14 - цифрові. На платформі є 32 Кб Flash-пам’яті.

Arduino Uno - це платформа, яка побудована на базі мікроконтролера ATmega328 та призначена для програмування автономних мікропроцесорних об'єктів. Вона також може підключатися до програмного забезпечення, що виконується на комп'ютері.

Розпочнемо детальний розгляд платформи Arduino Uno 3 живлення. Взагалі в Arduino $є$ три шляхи подання енергії для роботи: це живлення через шину USB, від спеціального роз'єму живлення 
на платі або входу Vin. В разі під’єднання платформи до комп’ютера за допомогою USB на плату подається живлення завдяки чотирипровідній структурі шини USB, де через 2 провідники передаються команди, а через два інших - живлення пристроїв. Таким чином на Arduino подається робоча напруга $5 \mathrm{~V}$. Ця напруга надходить на вхід стабілізатора напруги, на якому знижується до $+3,3 \mathrm{~V}$, що необхідно для живлення деяких окремих компонентів, які підключаються до Arduino. Для захисту від великих витрат струму на вході лінії живлення розробники встановили невеликий запобіжник на 500 мА, через який в разі деяких обставин буде здійснюватися захист USB-порту комп'ютера та плати Arduino від можливого виходу з ладу. На платі є роз'єм для під'єднання живлення, наприклад, від мережевого АC / DC-адаптера, акумулятора або батареї. На відміну від USB-порту, де передбачена стабільна напруга 5 V, роз'єм живлення розрахований на під'єднання до нього джерел живлення різної напруги. Діапазон цих значень коливається в межах від 6 до $20 \mathrm{~V}$. Разом 3 тим пряме під'єднання не придатне для компонентів схеми. Тому на вході живлення розробники поставили стабілізатори напруги (один на $5 \mathrm{~V}$, інший на $3,3 \mathrm{~V}$ ), а також два конденсатори та діод як елементи боротьби з шумом і захист від зміни полярності. Якщо під'єднати джерело живлення до виходу Vin на платі Arduino, то напруга потрапить на стабілізатор $5 \mathrm{~V}$ i на плату буде подаватися живлення. Це зручно у випадку використання батарей або акумуляторів без спеціальних роз'ємів живлення. В разі під'єднання Arduino автоматично вибирається джерело живлення 3 найбільшою напругою. Для цього використовується спеціальний елемент, який називається компаратор - це пристрій, на який порівнюється сигнал, що подається на нього з будь-яким опорним значенням. Якщо це значення перевищує опорне, через компаратор видається на виході логічна одиниця (в розглядуваному випадку +5 В).

B Arduino Uno передбачено ряд можливостей для здійснення зв'язку з комп'ютером, ще однією платформою Arduino або з іншими мікроконтролерами. У ATmega328 є приймач USART, що в перекладі означає «універсальний синхронно-асинхронний приймач-передавач». Через нього можна здійснювати послідовний зв'язок за допомогою цифрових виходів 0 (RX) та 1 (TX). Через мікроконтролер ATmega16U2 на платі забезпечується зв'язок цього приймача 3 USB-портом комп'ютера, що під час під'єднання до ПК дозволяє Arduino визначати як віртуальний СОМ-порт. Під час передавання даних через мікросхему-перетворювач USB-USART під час USB-з'єднання 3 комп'ютером на платі будуть мигати світлодіоди RX i TX.

Мікроконтролер Atmega328P $\epsilon$ основним обчислювальним елементом платформи. В узагальненому вигляді будь-який мікроконтролер можна розділити на три складові частини:

1. Обчислювальний блок (арифметико-логічний пристрій або процесор). Саме цей блок $є$ головною частиною системи та призначений для виконання різних операцій iз числами. Послідовність цих операцій називається програмою. Кожна операція кодується у вигляді числа та записується в пам'ять мікроконтролера.

2. Модуль пам'яті - це спеціалізований електронний пристрій, що являє собою набір комірок, у кожній із яких може зберігатися одне число. Саме тут зберігається програма та інші команди мікроконтролера. Пам'ять ділиться на оперативну - ОЗУ (оперативний запам'ятовуючий пристрій) $\mathrm{i}$ постійну - ПЗУ (постійний запам'ятовуючий пристрій). Принципова різниця між цими видами пам'яті в тому, що у випадку з оперативною пам'яттю, під час увімкнення живлення мікроконтролера записані значення не зберігаються та існують тільки до тих пір, поки є живлення. Наприклад, така пам'ять використовується для зберігання будь-яких проміжних результатів обчислень. А дані, що зберігаються в постійній пам'яті, не залежать від наявності живлення та можуть бути використані відразу після включення.

3. Порти введення-виведення (ніжки). Деякі порти призначені для подання живлення та зв'язку з іншими компоненти, що під'єднуються до мікроконтролера, але більшість із них є портами введеннявиведення, що призначені для забезпечення управління через мікроконтролер різними датчиками, модулями, світлодіодами, транзисторами тощо. Переважна більшість цих портів були виведені розробниками Arduino на периметр плати та, для зручності роботи, підписані.

На платі Arduino Uno для двох мікроконтролерів відповідно встановлені два кварцові резонатори 3 частотою 16 МГц. Через мікроконтролер рахуються імпульси та за їх кількістю повідомляється, скільки часу пройшло від запуску будь-якої процедури. На платформі Arduino Uno є кнопка, що називається кнопкою скидання, або RESET. Натискання на неї переводить мікроконтролер у вихідний стан, з якого починалося його функціонування [8].

Найбільш популярними середовищами для роботи з Arduino $\epsilon$ Arduino IDE (базове середовище, що грунтується на мові Processing), FLProg (графічне середовище, що орієнтоване на мови FBD та LAD), Fritzing (програма для проектування прототипів), Minibloq (графічне середовище, орієнтоване на навчання програмування) та Tinkercad (онлайн ресурс для імітації робочого процесу створення прототипів) [9]. 
Програмний пакет Fritzing може стати в нагоді на таких стадіях розробки, як складання прототипу схеми на макетній платі, а також для автоматичного генерування принципової схеми та друкованої плати. Цільова аудиторія програми - творчі люди, дослідники, дизайнери, радіоаматори, які працюють з електричними пристроями.

Fritzing створювався для Arduino. Він був розроблений у 2009 році в Потсдамському університеті прикладних наук за рахунок субсидій, які надаються державою на дослідження наукової програми під назвою «From prototype to product» (від прототипу до продукту). Середовище розробки Fritzing перекладене англійською, данською, іспанською, французькою, італійською, португальською, японською, китайською та російською мовами. Поширюється програмне забезпечення безкоштовно та сумісне з усіма операційними системами.

Програмний пакет Fritzing можна завантажити з офіційного сайту http://fritzing.org/. Iнтерфейс програми не складний, але вимагає певного вивчення на початковому етапі. Під час запуску програми відкривається вікно привітання (рис. 1). Тут розміщений блог, поради дня, можна відкрити й подивитися останні скетчі та запропоновані послуги зі створення професійних друкованих плат.

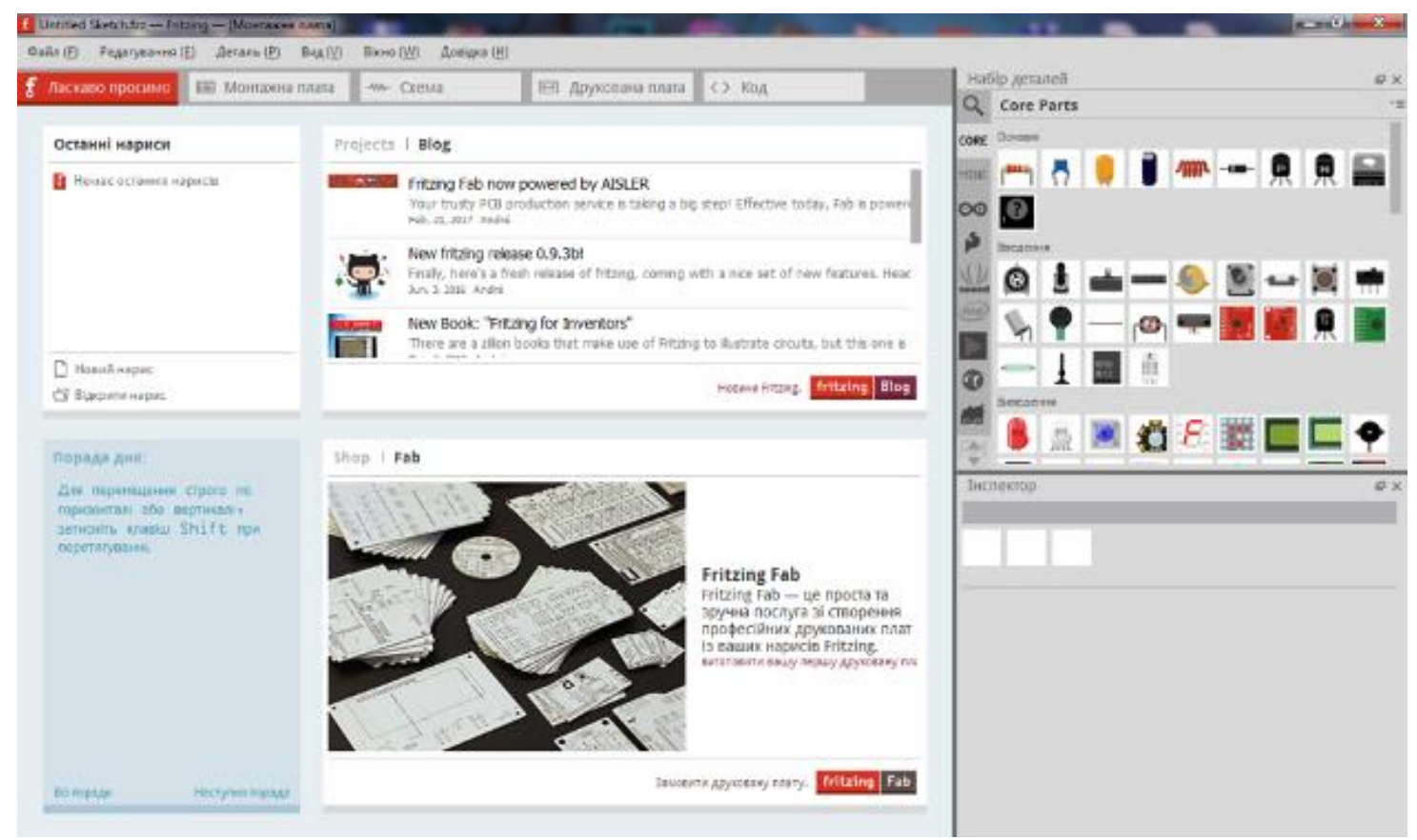

Pис. 1. Вікно привітання програми Fritzing

Основне вікно середовища - це робочий стіл для проектування плати. Робота над новим проектом у Fritzing починається з вибору готових компонентів, повний перелік яких розташований у верхньому кутку робочого вікна 3 правого боку. Тут $є$ цілий набір радіодеталей: конденсатори, транзистори, резистори, світлодіоди, батарейки, кнопки та ін. Під час наведення курсору на пристрій з'являється підказка 3 характеристиками, а під вікном із переліком компонентів - інспектор, де показані зовнішній вигляд, позначення на принципових схемах та властивості.

В програмному продукті Fritzing підтримується широкий вибір платформ Arduino: Uno, Galileo, Yun, BT, Mega 2560 (rev 3), Due, Nano (rev 3) та інші. У разі вибору потрібної плати у вікні «Інспектор» наводиться опис основних характеристик платформи.

Додатково надається велика колекція пристроїв для робототехніки: мотори, далекоміри, динаміки, пищалки, сервоприводи, крокові двигуни, LCD та цифрові індикатори й багато іншого. Також можна створювати власні елементи та оновлювати існуючу базу. Схема доступна для малювання (як у вікні «Макетна плата», так і у вікні «Принципова схема») простим переміщуванням потрібних компонентів на робоче поле. $€$ функція автотрасування.

Під час вибору вікна «Друкована плата» можна приступити до розведення провідників та розміщення елементів. Результат роботи експортується в pdf-файл для роздруковування на принтері 3 подальшим виготовленням плати за методом нанесення малюнка на фольгований текстоліт за допомогою гарячої праски.

В програмному пакеті Fritzing передбачено спеціальне середовище розробки програмного коду, що дозволяє писати та редагувати ескіз, а також відправляти його на мікроконтролер відповідної платформи, визначивши попередньо, через який послідовний порт вона під'єднана до ПК.

Для тих, хто тільки почав ознайомлення з побудовою електронних схем на базі Arduino, $є$ велика кількість прикладів під'єднання плат розширення та електронних компонентів із програмним кодом. 
За готовими схемами можна одразу приступати до виконання проектів.

Зручні інструменти в програмі призначені для максимального полегшення перетворення ідеї в цифровий проект. Створювані схеми виходять надійними та не потребують доопрацювання для запуску виробництва плат.

Fritzing можна використовувати на факультативних заняттях або в гуртках 3 інформатики, починаючи 38 класу. До цього часу школярі вже знають закон Ома, з'єднання провідників, основні алгоритмічні структури, уміють збирати електричні кола.

У процесі роботи 3 готовими міні-проектами Arduino учні навчаються використовувати інструкції, у яких $є$ теоретична частина, схема збірки, приклад ескізу та завдання для самостійного виконання. Але виконавши велику кількість таких робіт, школяр, на жаль, практично ніколи не зможе зібрати схему самостійно. У такому випадку допомагає використання програмного пакету Fritzing, через який надаються інтуїтивно зрозумілі підказки, як це зробити. Однак, у більшості випадків, з цим програмним забезпеченням працюють ті, хто розробляє довгострокові та складні проекти, як-от «Розумний будинок» та інші.

На заняттях в гуртках з інформатики або робототехніки учням можна запропонувати розробити принципову схему пристрою та створити іiі у вигляді з'єднання макетів елементів за допомогою спеціального програмного забезпечення Fritzing.

За допомогою Fritzing також можна успішно реалізувати довгострокові проекти, що виконуються в освітній установі старшокласниками. Крім того, використання програмного забезпечення дає можливість побачити, які компоненти доцільніше використовувати під час виконання проекту. Це дозволяє зробити необхідну закупку з мінімальними фінансовими витратами, що нині дуже актуально.

На офіційному сайті розробників програми Fritzing на вкладці «Навчання» наведено ряд посилань на ресурси та матеріали, за якими можна ознайомитися 3 особливостями роботи 3 середовищем. Для прикладу розглянемо всі етапи створення електронної гри «Hunter».

Опишемо ідею гри «Hunter». С 8 світлодіодів: 7 - одного кольору (червоного), а один - іншого (синього). Ще $\epsilon$ перемикач. Світлодіоди засвічуються в довільному порядку. Задача - натиснути перемикач після того, як засвітиться синій світлодіод, і до того, як засвітиться будь-який червоний світлодіод. Таким чином, необхідні плата Arduino Uno, 8 світлодіодів (7 червоних та 1 синій), 8 резисторів, перемикач та з'єднувальні провідники.

Перед тим, як почати роботу над новим проектом, розробники рекомендують побудувати реальну електронну схему та переконатися, що вона функціонує правильно, а потім уже переходити до відтворення схеми в Fritzing. Сконструювавши схему, переконуємося, що вона функціонує. Отже, можна приступати до відтворення іiї в середовищі.

Шляхом переміщування деталей із бібліотеки, що знаходиться в правому верхньому куті вікна програми, створюється наочна схема проекту. Провід створюємо миттєво, клацаючи на виході та переміщуючи курсор від деталі. Провідник можна зігнути. Створити точки згину можна просто, клацнувши на провідникові та перемістивши їх у потрібне місце. Схему можна редагувати: переміщувати, копіювати, вставляти елементи. $Є$ множинний вибір, обертання, історія відмін та багато іншого - усі ці функції інтегровані в розділи середовища Fritzing. Використовуючи функції в рядку меню, розташованого під зображенням деталі, можна обертати та віддзеркалювати компоненти схеми. Щоб вилучити деталь, потрібно вказати на неї та клацнути клавішою мишки, після чого натиснути BACKSPACE. Роз'єми, що під'єднані правильно, підсвічуються зеленим кольором, а ті, що неправильно - червоним. Якщо вказати та утримувати будь-який вихід, через Fritzing будуть вказані усі еквіпотенціальні роз'єми. Це корисно, якщо потрібно побачити весь набір з'єднань, прив'язаних до цього конкретного виходу. Коли компонент схеми вибраний, відповідні відомості про деталь відобразяться в «Інспекторі» деталей, де можна одразу змінити його властивості.

До виходів D2-D9 на платі Arduino Uno було під'єднано 8 світлодіодів діаметром 5 мм, із яких сім червоних та 1 синій. Для того, щоб змінити колір світлодіода (в розглядуваному випадку червоний на синій), потрібно його виокремити та в «Інспекторі» вибрати з переліку потрібний.

Наступним кроком $є$ під'єднання резисторів. Номінал резисторів залежить від типу світлодіодів, що використовуються в проекті. Також потрібно знати максимальний робочий струм та падіння напруги на світлодіоді. У червоних світлодіодів падіння напруги становить $2 \mathrm{~V}$ та максимальний струм - $20 \mathrm{~mA}$.

Тобто на один світлодіод червоного кольору потрібен обмежувальний резистор з опором 15 Ом. У синіх світлодіодів падіння напруги становить $3,6 \mathrm{~V}$ та максимальний струм - $20 \mathrm{~mA}$. Аналогічно розраховується номінал резистора - 7 Ом. Обираємо номінали у вікні «Інспектор». Якщо в переліку немає резистора потрібного номіналу, вибираємо його 3 найближчими характеристиками. Таким чином, для синього світлодіоду можна вибрати резистор номіналом 6,8 Ом із переліку. 
Останнім етапом $є$ під’єднання кнопки до виходу D10. Для всіх електронних компонентів схеми $\epsilon$ спільний вихід, що йде на вихід GND платформи Arduino Uno. Також можна додати примітки (нижне меню) або мітки (клацання правою кнопкою мишки після встановлення курсора на зображення деталі) до свого ескізу.

Після розставлення всіх деталей схеми та з'єднання їх провідниками, отримається ескіз, дуже схожий на реальну схему (рис. 2).

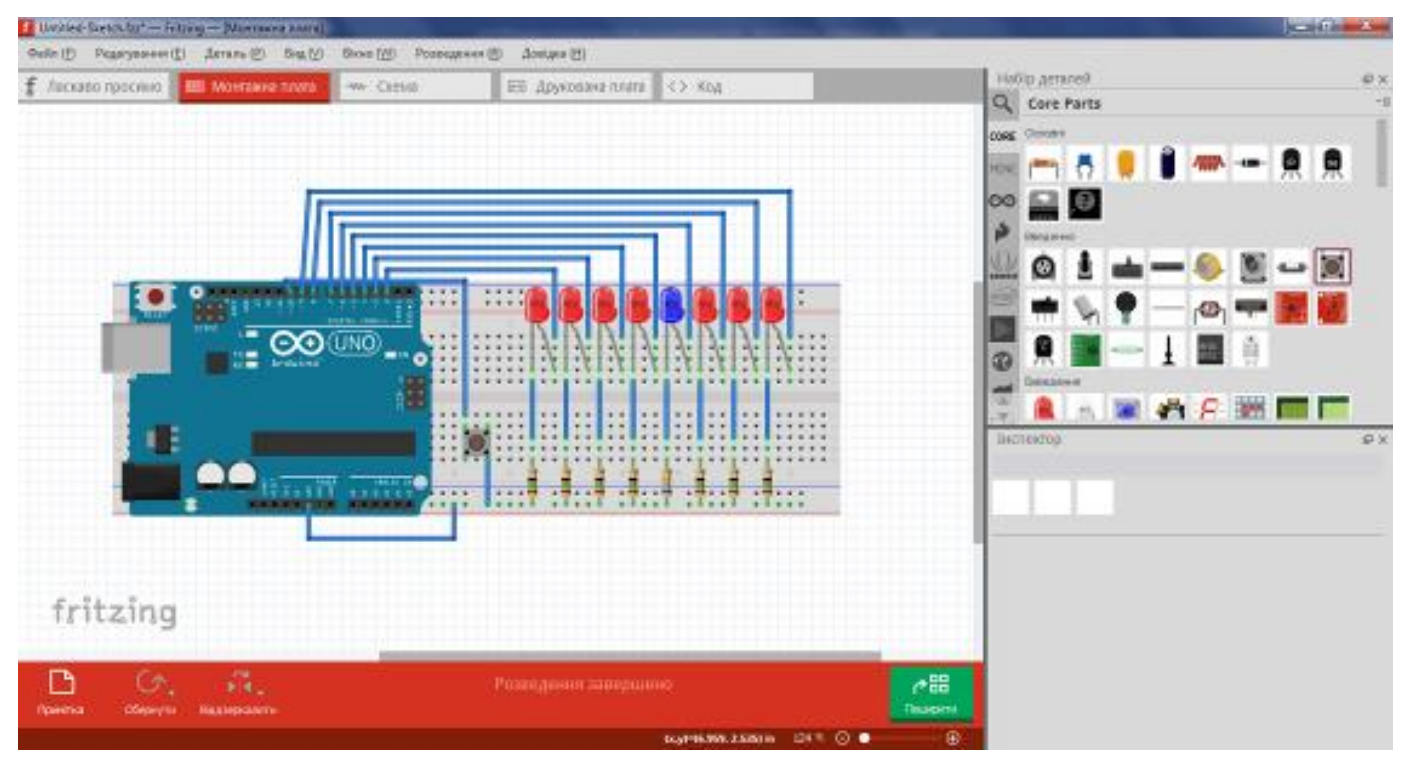

Рис. 2. Макет гри на платформі Arduino Uno

Використання Fritzing надає можливість здійснювати перемикання між способами подання проекту: макетом, схемою та друкованою платою. Будь-яке 3 цих подань може використовуватися в якості основного робочого середовища проекту та може бути вибрано в будь-який час. Оскільки макет проекту вже готовий, то, перейшовши на вкладку «Схема», побачимо автоматично згенеровану схему. Компоненти на схемі розташовані хаотично, тому потрібно змінювати їх місце розташування власноручно.

Розставивши компоненти в логічному порядку, можна приступати до розведення провідників. В програмному середовищі Fritzing передбачено корисну функцію «Розведення». Після натискання на відповідну кнопку в рядку меню внизу вікна за програмою запуститься процес автотрасування. Як видно на рис. 3, 3'явилися не всі необхідні для роботи схеми провідники та створено багато зайвих перегинів.

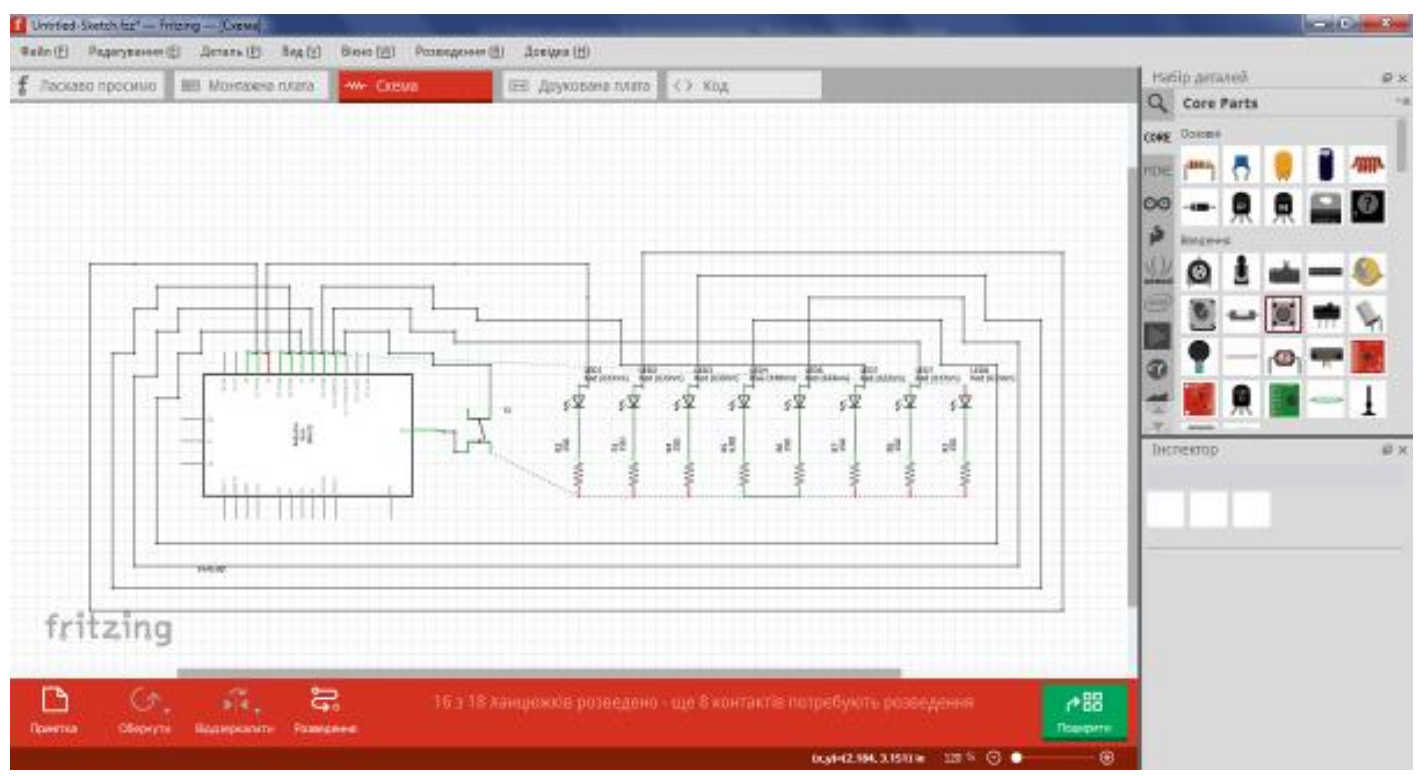

Рис. 3. 3'єднання елементів схеми за допомогою функиії "Розведення»

Здійснивши розведення самостійно, отримуємо схему гри на платформі Arduino Uno. Кожен елемент на схемі підписаний. Він має назву та характеристики. Підписи та номінал можна змінювати в меню «Інспектор» аналогічно до того, як це робили в описі «Макет».

Виготовлення друкованої плати для розглядуваного проекту не є доцільним, оскільки схема 
невелика та легко виконується на макетній платі. Отже можна приступати до створення програмного коду. Перейшовши в меню «Код» можна одразу починати його записувати.

Спочатку ініціалізуємо виходи, до яких під'єднані світлодіоди: int pin $=0$. Далі виконується функція setup(). Вона запускається один раз: після кожного під'єднання живлення або автоматичного вимкнення плати Arduino. У тілі зазначеної функції додамо фрагмент коду налаштування, за яких виходи D2-D9 будуть означені OUTPUT та світлодіоди, під'єднані до них, будуть вимкнені. Також потрібно виходу D10 надати значення HIGH, тобто високий рівень сигналу.

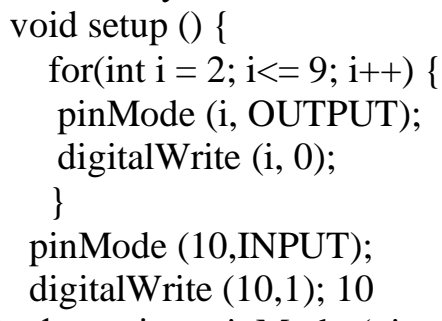

За функцією pinMode (pin, mode) встановлюється режим роботи заданого виходу (pin) як входу або виходу. Зазначеному виходові надається відповідно значення INPUT або OUTPUT. За функцією digitalWrite (pin, value) надається значення HIGH (1) або LOW (0) на вихід (pin). Якщо вихід був встановлений в режимі OUTPUT за функцією pinMode (), то для значення HIGH напруга на відповідному виході буде $5 \mathrm{~V}$, для LOW - 0V (земля).

Після однократного виконання функції setup () запускається функція loop (). За нею задається нескінченний цикл, тобто код, що міститься в ній, буде повторюватися. В наведеному програмному коді до функції loop () включено послідовність функцій, за якими описується логіка гри: у випадковому порядку засвічується одним із світлодіодів. Якщо натискається кнопка, коли світиться червоний світлодіод, - виконується функція flub: почергово засвічуються світлодіоди зліва та справа від синього. Якщо кнопку натиснуто, коли світиться синій світлодіод, - виконується функція vin: почергово засвічуються всі світлодіоди.

У рядку меню внизу вікна можна вибрати з переліку платформу, плату та послідовний порт, до якого під'єднано Arduino.

Далі потрібно під'єднати платформу Arduino Uno до комп’ютера та встановити драйвер. Для цього необхідно завантажити папку 3 драйвером на персональний комп'ютер, наприклад, перейшовши за посиланням http://www.arduined.eu/ch340g-converter-windows-7-driver-download/. Після того, як драйвер завантажено, можна переходити до його встановлення.

Платформа Arduino Uno під’єднується до персонального комп’ютера за допомогою USB. Після під'єднання плати на ній має засвітися зелений світлодіод живлення. Після цього в диспетчері пристроїв комп'ютера шукаємо новий пристрій, що під'єднаний через USB. Бачимо, що пристрій визначився як USB2.0-Serial. У контекстному меню обираємо пункт «Оновити драйвери». 3'являється меню вибору способу пошуку програмного забезпечення для пристрою. Виконуємо пошук драйвера на комп'ютері в ручному режимі. Після цього з'явиться вікно з повідомленням про успішність завершення інсталяції драйвера для пристрою. У диспетчері пристроїв перевіряємо коректність під'єднання, там повинен з'явитися новий пристрій, під'єднаний через СОМ порт.

Висновки. В рамках даного дослідження проведено аналіз навчальних програм з інформатики для 5-11 класів щодо вивчення елементів схемотехніки в шкільному курсі інформатики та виявлено, що елементи комп'ютерної схемотехніки розглядаються під час вивчення технічних характеристик та призначення основних складових персонального комп'ютера. Більш широко зазначений матеріал вивчається у 8 класі в школах з поглибленим вивченням інформатики. Були досліджені можливості використання мікроконтролерної платформи Arduino для вивчення елементів схемотехніки в шкільному курсі інформатики з використанням засобів програмного пакету Fritzing та виявлено його основні переваги:

- забезпечення швидкого та автоматизованого робочого процесу;

- зручний робочий інтерфейс з готовим набором мікросхем та електронних компонентів;

- створення повноцінних макетів друкованих плат;

- можливість експорту документів;

- безкоштовне використання.

Також було створено наочну електронну схему з використанням засобів програмного пакету Fritzing на прикладі електронної гри.

Отже, Arduino - відкритий програмний комплекс для виконання проектів різної складності, його доцільно використовувати для вивчення елементів схемотехніки в шкільному курсі інформатики, а для спрощення навчального процесу можна використовувати програмний пакет Fritzing, що 
призначений для побудови наочних електронних схем.

Програмний продукт Fritzing використовується в процесі фахової підготовки майбутній вчителів інформатики, математики та фізики в Житомирському держаному університеті імені Івана Франка.

\section{Список використаних джерел}

[1] STEM-освітаю. URL: https://imzo.gov.ua/stem-osvita/ (Дата звернення: 19.11.2019).

[2] STEMconnector. URL: https://www.stemconnector.com/research-resources/ (Дата звернення: 19.11.2019).

[3] STEM Education: Preparing for the Jobs of the Future: report. April 2012: URL: http://www.jec.senate.gov/public/_cache/files/6aaa7e1f-9586-47be-82e7-326f47658320/stemeducation---preparing-for-the-jobs-of-the-future-.pdf_(Дата звернення: 19.11.2019).

[4] Кривонос О. М., Кузьменко Є. В., Кузьменко С. В. Огляд платформи Arduino Nano 3.0 та перспективи використання під час навчального процесу. Інформаційні технології і засоби навчання. 2016.Том 56, № 6. С. 77-87.

[5] Биков В. Ю. Інформаційні технології і засоби навчання Київ.2008. 684 с.

[6] Гуржій А. М., Орлова I. В., Шут М. І., Самсонов В. В. Засоби навчання в загальноосвітніх навчальних закладах (теоретико - методологічні основи) Київ. 2001. 95 с.

[7] Richard Jaeger. Microelectronic Circuit Design. URL: https://ecedmans.files.wordpress.com/ 2014/03/microelectronic-circuit-design-4th-edition-jaeger.pdf_(Дата звернення: 19.11.2019).

[8] Основы Arduino для начинающих. Arduino изнутри - структура, составляющие и их назначение. Микроконтроллер ATmega328P. URL: https://pikabu.ru/story/vyipusk_3_osnovyi_arduino_dlya_ nachinayushchikh_arduino_iznutri_struktura_sostavlyayushchie_i_ikh_naznachenie_mikrokontroller_ atmega328p_4497606?fbclid=IwAR12p2g7hUTRgp9CkWMmVRk6vkfRmIZy5T9Mml69ZOXn1LHc 1YxGw_zqKAA (Дата звернення: 19.11.2019).

[9] Паладійчук Ю. Б., Руткевич В. С., Зінєв М. В., Лісовий І. О. Перспективи використання від критого програмного комплексу arduino для вивчення технічних дисциплін. Техніка в сільськогосподарському виробництві, галузеве машинобудування, автоматизація. 2018. Вип. 31. C. $158-164$.

[10] Боровик Д. В., Вовковінська Н. В., Войченко О.П., Дятленко С. М., Лапінський В. В. Програма курсу «Технічна творчість. Робототехніка», 5-9 класи. Комп'ютер у школі та сім'ї. 2017. №2-3. C. $138-139$.

[11] Морзе Н.В., Струтинська О.В., Умрик М.А. Освітня робототехніка як перспективний напрям розвитку STEM-освіти. Відкрите освітне середовище сучасного університету. 2018. № 5. С. 178187.

\section{References}

[1] STEM-education. URL: https://imzo.gov.ua/stem-osvita/. (in Ukrainian)

[2] STEMconnector URL: https://www.stemconnector.com/research-resources/.

[3] STEM Education: Preparing for the Jobs of the Future: report. April 2012. URL: http://www.jec.senate.gov/public/_cache/files/6aaa7e1f-9586-47be-82e7-326f47658320/stemeducation---preparing-for-the-jobs-of-the-future-.pdf.

[4] Kryvonos O.M., Kuzmenko Ye. V., Kuzmenko S. V. (2016) Survey and prospects of Arduino Nano 3.0 platform use in high school. Information Technologies and Learning Tools. Kiev. Vol 56, 6. P. 77-87.

[5] Bykov V. Yu. (2008) Information Technologies and Learning Tools. Kiev. 684 p.

[6] Gurzhij A. M., Orlova I. V., Shut M. I., Samsonov V. V., Means of studying general educational institutions (theoretical and methodological foundations). Kiev. 2001. 95 p. (in Ukrainian)

[7] Richard Jaeger. Microelectronic Circuit Design URL: https://ecedmans.files.wordpress.com/ 2014/03/microelectronic-circuit-design-4th-edition-jaeger.pdf.

[8] Arduino Basics for Beginners. Arduino from within - the structure that constitutes and their purpose. Microcontroller ATmega 328 P. URL: https://pikabu.ru/story/vyipusk_3_osnovyi_arduino_dlya_ nachinayushchikh_arduino_iznutri_struktura_sostavlyayushchie_i_ikh_naznachenie_mikrokontroller_ atmega328p_4497606?fbclid=IwAR12p2g7hUTRgp9CkWMmVRk6vkfRmIZy5T9Mml69ZOXn1LHc 1YxGw_zqKAA.

[9] Paladijchuk Yu. B., Rutkevy`ch V. S., Zinyev M. V., Lisovy`j I. O. (2018) Prospects for the use of the open-source software arduino for the study of technical disciplines. Machinery in agricultural production, industry machine building, automation. Vol. 31. p. 158-164.

[10] Borovyk D.V., Vovkovinska N.V., Voichenko O.P., Diatlenko S.M., Lapinskyi V.V. (2017) Course Program Technical Creativity. Robotics, grades 5-9 Computer at school and family. Vol. 2-3. p. 138139. (in Ukrainian) 
[11] Morze, N., Strutynska, O. \& Umryk, M. (2018) Educational Robotics as a prospective trend in STEMeducation development. Open educational e-environment of modern University. 5. P. 178-187. (in Ukrainian)

\title{
Oleksandr M. Kryvonos, Myroslava P. Kryvonos FRITZING IS A PROGRAM FOR CREATING VISUAL ELECTRONIC CIRCUITS
}

\begin{abstract}
The article analyzes the current state of the issue of STEM-education in general secondary education of Ukraine, considers the prospects of introducing elements of circuitry within the school course of computer science (CS) as one of the elements of STEM-education, moreover, it reviews the possibility of implementation of the mentioned part as one of the components of professional training of computer science teachers. The analysis of the recent researches and publications on a problem of use of electronic devices in educational process is carried out; the choice of the open software platform Arduino as an auxiliary didactic tool for studying the elements of computer circuitry is substantiated. The most common Arduino model series are described and the examples of their applied use in real-life projects are given. The main technical specs and features of Arduino Uno electronic components are given and explained. The Atmega328P microcontroller, the main computing center of the platform, and its main structural elements are considered in detail; in order to substantiate the offered method, a program suite for creating visual electronic circuits Fritzing is taken as an example with detailed description of its functions and capabilities. This software product provides the opportunity to visually present the project in different forms (layout, scheme and/or printed circuit board). Any of these views can be used as the main work environment of the project and can be selected at any time. Fritzing has a library of ready-made projects, which greatly facilitates the learning process. For greater clarity, all the processes of creating a prototype of the electronic game "Hunter" in the Fritzing environment are described and illustrated, as well as a description of the process of creating the game itself. Mentioned software product is used in the process of professional training of future teachers of computer science, mathematics and physics at Zhytomyr Ivan Franko State University. The authors outline prospects of research in this area.
\end{abstract}

Keywords: STEM-education; circuitry engineering; electronic circuits; Arduino.

DOI 10.31392/NPU-nc.series 2.2020.22(29).16

УДК 371.13

Володимир Васильович Листопад

кандидат фізико-математичних наук, доцент доцент кафедри вищої математики ім. проф. Можара B.I. Національний університет харчових технологій, м. Київ, Україна

ORCID 0000000209741775 vlystopad@ukr.net

\section{РОЗВ'ЯЗУВАННЯ СИСТЕМ ЛІНІЙНИХ РІВНЯНЬ 3 КОМП'ЮТЕРНОЮ ПІДТРИМКОЮ}

Анотація. У статті показано можливість застосування електронних таблиць Microsoft Office Excel для розв'язування деяких задач з курсів алгебри та теорії чисел, електротехніки; презентовано спосіб розв'язування системи лінійних алгебраїчних рівнянь за допомогою методу Жордана-Гауса (повного виключення) з використанням Ms Excel; визначено переваги застосування даного методу над традиційними. Наведено приклади застосування теореми Кронекера-Капеллі, яка використовується для з'ясування питання про сумісність системи лінійних рівнянь будь-якої розмірності та їі розв'язок за позитивної відповіді на питання сумісності. Розкрито можливості, використання програми Ms Excel для розв'язування системи лінійних алгебраїчних рівнянь за методами Крамера, Гауса, перетворень (Жордана-Гауса), що виявляються в опосередкованому формуванні навичок програмування та у суттєвій економії часу на виконання цих завдань.

3 огляду на те, що в сучасній освіті простежується тенденція скорочення годин на вивчення математичних дисциплін, актуальним є впровадження інформаційних технологій в процес навчання за окремими темами курсу вищої математики, що дозволить урізноманітнити форми та способи оволодіння новим змістом; підвищить мотивацію навчальної діяльності студентів; дасть змогу студентам в короткий термін самостійно опрацьовувати матеріал та отримати нові знання та досвід застосування для їх подальшого використання у фаховій діяльності. Застосування комп'ютера на занятті в 4-5 разів збільшить обсяг опрацьованого матеріалу, сприятиме формуванню у студентів навичок елементів програмування, самоконтролю та перевірки правильності результатів. У роботі 